\title{
ТАКТИКА ВИБОРУ ЛІКУВАЛЬНО-ПРОФІЛАКТИЧНИХ ЗАХОДІВ У ОСІБ ІЗ РІЗНИМИ ПСИХОФІЗІОЛОГІЧНИМИ СТАНАМИ ПРИ ЛІКУВАННІ ЗАХВОРЮВАНЬ ПАРОДОНТА
}

ДВНЗ «Тернопільський державний медичний університет імені І.Я. Горбачевського МОЗ України», м. Тернопіль, Україна

Мета: обґрунтувати вибір лікувально-профрілактичних схем лікування захворювань тканин пародонта в осіб молодого віку залежно від психофізіологічного стану організму.

Матеріали і методи. У дослідженні взяли участь 48 осіб із запальними захворюваннями тканин пародонта та 52 пацієнти із запально-дистрофічними хворобами цього органа з різним психофрізіологічним станом організму, які були поділені на різні лікувальні групи залежно від обраної тактики лікування.

Результати. В основних лікувальних групах були застосовані лікувально-профрілактичні комплекси, що включали: гігієнічне навчання та виховання; індивідуальний вибір засобів догляду за порожниною рота з урахуванням індексу гігієни Гріна-Вермільйона, інтенсивності ураження тканин пародонта за індексом РМА, та здійснення просесійної гігієни порожнини рота. Схема лікування пацієнтів контрольних лікувальних груп була передбачена діючими стандартами лікування захворювань тканин пародонта.

Висновки. При лікуванні захворювань пародонта у цих осіб важливим етапом $€$ індивідуальна та диференційована розробка і впровадження місцевих та загальних лікувальних заходів з урахуванням клінічного та психосоматичного станів пацієнтів.

КЛЮчОВІ СЛОВА: психофізіологія; дезадаптація; гінгівіт; пародонтит; молодий вік, лікування.

Епідеміологічні дослідження останніх років свідчать про високу розповсюдженість стоматологічних захворювань в різних статевих, вікових і соціальних групах населення, а також визначають фрактори, що впливають на ріст і розвиток стоматологічної захворюваності $[1,5]$. Поширеність основних стоматологічних захворювань серед дорослого населення останніми роками має тенденцію до зростання, незважаючи на стрімкий розвиток галузі, що передбачає запровадження у практику новітніх методик і технологій лікування [2].

За даними ВОО3, захворювання тканин пародонта залишаються невирішеними сучасною медициною, а їх актуальність визначається великим попитом населення на ефективне лікування цих захворювань, а найголовніше - профрілактику виникнення $[3,4]$. Роль психологічних характеристик особистості у розвитку та лікуванні стоматологічних захворювань обґрунтована рядом досліджень вітчизняних і закордонних вчених, в яких розглядалися особливості емоційно-особистісної сфрери пацієнтів із різною стійкістю до захворювань твердих тканин зубів та пародонта [6-8].

Мета дослідження: обґрунтувати вибір лікувально-профрілактичних схем лікування захворювань тканин пародонта в осіб молодого віку залежно від психофрізіологічного стану організму.

Матеріали і методи. У дослідженні взяли участь 48 осіб із запальними захворюваннями тканин пародонта (33ТП) та 52 пацієнти із запально-дистрофрічними захворюваннями тканин пародонта (ЗДЗТП) із різним психофрізіологічним станом організму.

Основні лікувальні групи (ОЛГ) включали 27 досліджуваних із запальними захворюваннями тканин пародонта та 32 пацієнти із запальнодистрофічними ураженнями тканин пародонта, де лікування та профрілактику захворювань тканин пародонта проводили відповідно до розроблених лікувально-профрілактичних комплексів. До контрольних лікувальних груп (КЛГ) увійшли 21 пацієнт із З3ТП та 20 осіб з ЗДЗТП. Пацієнти КлГ отримували лікування та профілактику відповідно до передбачених діючих стандартів лікування генералізованих захворювань тканин пародонта. Місцеві та загальні лікувальні заходи розробляли диференційовано з урахуванням клінічного та психосоматичного станів пацієнтів основних лікувальних груп. Поділ пацієнтів ОЛГ та КЛГ наведено у таблиці 1.

Результати дослідження та їх обговорення. В основних лікувальних групах були застосовані лікувально-профілактичні комплекси, доцільність використання яких була обґрунтована у результаті дослідження, що передбачало: гігієнічне навчання та виховання; індивідуальний вибір засобів догляду за порожниною рота з урахуванням індексу гігієни Гріна-Вермільйона, інтенсивності 
Таблиця 1. Поділ пацієнтів на лікувальні групи із захворюваннями тканин пародонта та різним психофрізіологічним станом організму

\begin{tabular}{|c|c|c|c|c|c|c|}
\hline \multirow{2}{*}{$\begin{array}{c}\text { Захворювання } \\
\text { пародонта }\end{array}$} & \multirow{2}{*}{$\begin{array}{c}\text { Групи } \\
\text { дослідження }\end{array}$} & \multicolumn{5}{|c|}{ Типи психофізіологічних реакцій дезадаптації } \\
\hline & & Без РПД & РПД & CACK & ГHP & HР3П \\
\hline \multirow{2}{*}{$\begin{array}{l}33 T П \\
(n=48)\end{array}$} & $\begin{array}{c}\text { І основна } \\
\text { (ОЛГ) (n=27) }\end{array}$ & $\frac{6}{22,22 \%}$ & $\frac{11}{40,74 \%}$ & $\frac{6}{22,22 \%}$ & $\frac{2}{7,41 \%}$ & $\frac{2}{7,41 \%}$ \\
\hline & $\begin{array}{l}\text { I контрольна } \\
(\text { КЛГ) }(\mathrm{n}=21)\end{array}$ & $\frac{4}{19,05 \%}$ & $\frac{9}{42,86 \%}$ & $\frac{4}{19,05 \%}$ & $\frac{2}{9,52 \%}$ & $\frac{2}{9,52 \%}$ \\
\hline \multirow{2}{*}{$\begin{array}{c}\text { ЗДЗТП } \\
(n=52)\end{array}$} & $\begin{array}{c}\text { II основна } \\
(\text { (ЛГ) }(\mathrm{n}=32)\end{array}$ & $\frac{5}{15,63 \%}$ & $\frac{9}{28,13 \%}$ & $\frac{4}{12,50 \%}$ & $\frac{8}{25,00 \%}$ & $\frac{6}{18,74 \%}$ \\
\hline & $\begin{array}{c}\text { II контрольна } \\
\text { (КЛГ) }(\mathrm{n}=20)\end{array}$ & $\frac{3}{15,0 \%}$ & $\frac{6}{30,0 \%}$ & $\frac{3}{15,0 \%}$ & $\frac{4}{20,0 \%}$ & $\frac{4}{20,0 \%}$ \\
\hline
\end{tabular}

Примітки: РПД - реакції психофізіологічної дезадаптації; САСК - соматогенний астенічний симптомокомплекс; ГНР - гострі невротичні розлади; НРЗП - невротичні розлади із затяжним перебігом.

ураження тканин пародонта за індексом РМА, та здійснення професійної гігієни порожнини рота.

Місцеві лікувально-профрілактичні заходи в осіб молодого віку із З3ТП включали:

- антисептичну обробку порожнини рота за допомогою ополіскувачів, що містять хлоргексидин біглюконат («Perio-AID 0,12 \%», «Meridol Med $\mathrm{CHX}-0,2 \% »$, «Curaprox Curasept 0,12\%», «Eludril $0,10 \% ») ;$

- аплікації на ясна гелю «Perio-AID» у хворих із З3ТП проводили:

- 3 процедури щодня; з домашнім використанням упродовж 4 діб при РПД та в осіб без РПД;

- 3-5 процедур щодня; 3 домашнім використанням упродовж 5 діб при САСК;

- 5-7 процедур щодня; 3 домашнім використанням упродовж 7 діб при ГНР та НРЗП.

Загальна терапія в осіб молодого віку з з3ТП включала:

- для покращення мікроциркуляції тканин пародонта та попередження проникності капілярів - препарат «Аскорутин» призначали:

- по 1 таблетці (0,5 г) 1 раз на добу впродовж 2 тижнів при РПД, САСК та в осіб без РПД;

- по 1 таблетці 2 рази на добу впродовж 1 місяця при ГНР та НРЗП;

- для загального зміцнення організму - препарат «Аевіт» призначали по 1 таблетці (0,5 г) 2 рази на добу:

- протягом 1 місяця при РПД, САСК та в осіб без РПД;

- протягом 3 місяців при ГНР та НРЗП;

- для покращення ремоделювання кісткової тканини призначали препарат «Кальцемін»:

- по 1 таблетці на добу протягом 1 місяця при РПД, САСК та в осіб без РПД;

- по 2 таблетки на добу протягом 1 місяця, 3 повторним курсом кожні 3 місяця при ГНР та НРЗП.

У пацієнтів із ЗДЗТП місцево, для антисептичної обробки порожнини рота застосовували хлоргексинвмісні ополіскувачі, після чого проводили фротодинамічну терапію (ФДТ) за допомогою апарату для озонотерапії «Ozonymed»:
- по 5 процедур через добу в осіб із РПД та без РПД;

- по 5-6 процедур щодня у хворих із САСК;

- по 6-8 процедур щодня у хворих із ГНР та НРЗП.

Усім особам молодого віку, незалежно від психосоматичного стану організму, рекомендували застосовувати аплікації з гелем «Perio-AID» у домашніх умовах.

У хворих із З3ТП загальні лікувальні заходи включали:

- для покращення мембранопротекторних, антигіпоксичних явищ, стимуляції симпатоадреналової системи - препарат «Мілдронат» призначали:

- по 1 капсулі (250 г) 1 раз на добу впродовж 4 тижнів хворим без РПД та з РПД;

- по 1 капсулі 1 раз на добу впродовж 5 тижнів iз СACK;

- по 2 капсули 2 рази на добу впродовж 6 тижнів пацієнтам із ГНР та НРЗП;

- для покращення роботи дихальної, серцевосудинної, імунної систем, енергетичного обміну, роботи головного мозку - препарати «Бурштинова кислота» та «Коензим Q10» (дія останнього $€$ більш вираженою) застосовували:

- по 1 таблетці «Бурштинова кислота» 3 рази на добу впродовж 1 місяця в осіб без РПД та з РПД;

- по 1 капсулі «Коензим Q10» 2 рази на добу впродовж 1 місяця у хворих із САСК, ГНР, НРЗП;

- для покращення ремоделювання кісткової тканини - препарат «Остеогенон» призначали:

- по 1 таблетці 2 рази на добу протягом 1 місяця з повторними курсами кожні 6 місяців при РПД та без РПД;

- по 2 таблетки 2 рази на добу протягом 1 місяця з повторними курсами кожні 4 місяці.

Призначення препаратів загальної дії у хворих ОлГ проводили при консультативній допомозі та під наглядом лікарів-терапевтів.

Пацієнти контрольних лікувальних груп отримували лікувальний комплекс, передбачений діючими стандартами лікування захворювань тканин пародонта (наказ МО3 від 28.12.2004 № 502). 
Схема лікування КЛГ включала: професійну гігієну ротової порожнини, призначення місцево антисептиків, нестероїдних протизапальних препаратів залежно від ступеня тяжкості захворювань тканин пародонта, санацію ротової порожнини, ортодонтичне і хірургічне лікування (за показаннями). За стандартами проводили гігієнічне навчання індивідуальному догляду за порожниною рота, призначали лікувально-профрілактичні зубні пасти, що містять антисептики, екстракти лікарських трав, макро- і мікроелементи (у разі наявності рентгенологічних змін у тканинах пародонта), ополіскувачі, що містять антисептики.

\section{Висновки}

При лікуванні захворювань пародонта у цих осіб важливим етапом є індивідуальна та диференційована розробка і впровадження місцевих та загальних лікувальних заходів з урахуванням клінічного та психосоматичного станів пацієнтів.

Перспективи подальших досліджень будуть спрямовані на оцінку результатів застосування розроблених та впроваджених лікувально-профрілактичних комплексів у пацієнтів із захворюваннями тканин пародонта з різним психофрізіологічним станом організму в найближчі та віддалені терміни лікування.

\section{Список літератури}

1. Григорова А. О. Психофрізіологічні реакції у пацієнтів із запальними захворюваннями та з пошкодженнями щелепно-лицьової ділянки: взаємозв'язок з індикаторами фрункціонального стоматологічного статусу / А. О. Григорова // Психіатрія, неврологія та медична психологія. - 2015. - Вип. 2, № 2. - С. 53-59.

2. Дурягіна Л. Х. Ефрективність комплексної терапії і профрілактики захворювань пародонта у віддалені терміни спостереження за даними психологічного обстеження пацієнтів / Л. Х. Дурягіна, К. М. Косенко, В. А. Вербенко // Вісник стоматології. - 2013. - № 3. - С. 24-29.

3. Кутельмах О. І. Метод лікування генералізованого пародонтиту із застосуванням нанорозмірної композиції Метроксан і гелю Холісал / О. І. Кутельмах // Вісник Вінницького національного медичного університету. - 2013. Вип. 17, № 1. - С. 176-179.

4. Литовченко І. Ю. Роль психологічного тестування в прогнозуванні захворювань тканин пародонта / І. Ю. Литовченко, Т. О. Петрушанко // Вісник проблем біології і медицини. - 2017. - Вип. 4 (2). - С. $223-225$.

5. Психологічні характеристики людини в прогнозуванні хвороб тканин пародонта / Т. О. Петрушанко, І. Ю. Литовченко, М. О. Артюх [та ін.] // Український стоматологічний альманах. - 2014. - № 5-6. - С. 32-34.

6. Череда В. В. Гендерні індивідуально-психологічні характеристики осіб молодого віку залежно від стоматологічного статусу / В. В. Череда // Актуальні проблеми сучасної медицини: Вісник української медичної стоматологічної академії. - 2014. - № 2 (46). - С. 114-116.

7. Череда В. В. Застосування нових діагностичних методів у прогнозуванні ризику виникнення запальних захворювань пародонта / В.В.Череда, Т. О. Петрушанко // Актуальні проблеми сучасної медицини: Вісник української медичної стоматологічної академії. - 2015. - Т. 15, Вип. 2. - С. 75-79.

8. Череда В. В. Оцінка ризику розвитку запальних захворювань пародонта в осіб молодого віку із різним стоматологічним статусом / В. В. Череда // Актуальні проблеми сучасної медицини: Вісник української медичної стоматологічної академії. - 2013. - № 3 (43). - С. 74-77.

\section{References}

1. Hryhorova, A.O. (2015). Psykhofiziolohichni reaktsii u patsiientiv iz zapalnymy zakhvoriuvanniamy ta z poshkodzhenniamy shchelepno-lytsovoi dilianky: vzaiemozviazok z indykatoramy funktsionalnoho stomatolohichnoho statusu [Psychophysiological reactions among patients with inflammatory diseases and damage to the maxillofacial region: relationship with functional indicators dental status]. Psykhiatriia, nevrolohiia ta medychna psykholohiia - Psychiatry, Neurology and Medical Psychology, 2(2), 53-59 [in Ukrainian].

2. Duriahina, L.Kh., Kosenko, K.M. \& Verbenko, V.A. (2013). Efektyvnist kompleksnoi terapii i profilaktyky zakhvoriuvan parodonta $u$ viddaleni terminy sposterezhennia za danymy psykholohichnoho obstezhennia patsiientiv [The effectiveness of complex therapy and prophylaxis of periodontal diseases in the long-term observation of the data of psychological examination of patients]. Visnyk stomatolohii - Herald of Stomatology, (3), 24-29 [in Ukrainian].

3. Kutelmakh, O.I. (2013). Metod likuvannia heneralizovanoho parodontytu iz zastosuvanniam nanorozmirnoi kompozytsii Metroksan i heliu Kholisal [Treatment of generalized periodontitis with the use of nanosized composition Metroxane and Kholisal gel]. Visnyk Vinnytskoho natsionalnoho medychnoho universytetu - Journal of Vinnytsia National Medical University, 17 (1), 176-179 [in Ukrainian].

4. Lytovchenko, I.Yu., \& Petrushanko, T.O. (2017). Rol psykholohichnoho testuvannia v prohnozuvanni khvorob tkanyn parodonta [The role of psychological testing in the prognosis of periodontal tissues diseases]. Visnyk problem biolohii $i$ medytsyny - Bulletin of Problems in Biology and Medicine, 2 (4), 223-225 [in Ukrainian].

5. Petrushanko, T.O., Lytovchenko, I.Yu., Artiukh, M.O., Chechotina, S.Yu., \& Kotelevska, N.V. (2014). Psykholohichni kharakterystyky liudyny $v$ prohnozuvanni khvorob tkanyn parodonta [Psychological characteristics of human in prognosing of parodontium tissues diseases]. Ukrainskyi stomatoloichnyi almanakh - Ukrainian Dental Almanac, 5-6, 32-34 [in Ukrainian].

6. Chereda, V. V. (2014). Henderni individualno-psykholohichni kharakterystyky osib molodoho viku zalezhno vid stomatolohichnoho statusu [Gender-related individual and psychological characteristics of young adults depending on their oral status]. Aktualni problemy suchasnoi medytsyny: Ukrainskyi medychnyi stomatolohichnyi akademii - Actual Problems of Modern Medicine: Journal of Ukrainian Medical Stomatological Academy, 14 (2 (46)), 114-116 [in Ukrainian]. 
7. Chereda, V.V., \& Petrushanko, T.A. (2015) Zastosuvannia novykh diahnostychnykh metodiv u prohnozuvanni ryzyku vynyknennia zapalnykh zakhvoriuvan parodonta [New diagnostic techniques to assess risk of inflammatory periodontal diseases]. Aktualni problemy suchasnoi medytsyny: Visnyk Ukrainskoi medychnoi stomatolohichnoi akademii - Actual Problems of Modern Medicine: Journal of Ukrainian Medical Stomatological Academy, 15 (2), 75-79 [in Ukrainian].

8. Chereda, V.V. (2013). Otsinka ryzyku rozvytku zapalnykh zakhvoriuvan parodonta v osib molodoho viku iz riznym stomatolohichnym statusom [The influence of dental status on the risk of inflammatory periodontal diseases in adolescents]. Aktualni problemy suchasnoi medytsyny: Visnyk Ukrainskoi medychnoi stomatolohichnoi akademii - Actual Problems of Modern Medicine: Journal of Ukrainian Medical Stomatological Academy, 3 (43), 74-77 [in Ukrainian].

\section{ТАКТИКА ВЫБОРА ЛЕЧЕБНО-ПРОФИЛАКТИЧЕСКИХ МЕРОПРИЯТИЙ В ЛИЦ С РАЗЛИЧНЫМИ ПСИХОФИЗИОЛОГИЧЕСКИМИ СОСТОЯНИЯМИ ПРИ ЛЕЧЕНИИ ЗАБОЛЕВАНИЙ ПАРОДОНТА}

М.А. Лучинский, Л.В. Пясецкая

ГВУЗ «Тернопольский государственный медицинский университет имени И.Я. Горбачевского МЗ Украины»,

г. Тернополь, Украина

Цель: обосновать выбор лечебно-просрилактических схем лечения заболеваний тканей пародонта у лиц молодого возраста в зависимости от психофизиологического состояния организма.

Материалы и методы. В исследовании принимали участие 48 человек с воспалительными заболеваниями тканей пародонта и 52 пациента с воспалительно-дистрофическими болезнями этого органа с различным психофизиологическим состоянием организма, которые были разделены на различные лечебные группы в зависимости от выбранной тактики лечения.

Результаты. В основных лечебных группах были применены лечебно-профиллактические комплексы, которые включали: гигиеническое обучение; индивидуальный выбор средств по уходу за полостью рта с учетом индекса гигиены Грина-Вермильйона, интенсивности поражения тканей пародонта по индексу РМА, и осуществление профессиональной гигиены полости рта. Схема лечения пациентов контрольных лечебных групп была предусмотрена действующими стандартами лечения заболеваний тканей пародонта.

Выводы. При лечении заболеваний пародонта в этих лиц важным этапом является индивидуальная и дифреренцированная разработка и внедрение местных и общих лечебных мероприятий с учетом клинического и психосоматического состояний пациентов.

КЛЮЧЕВЫЕ СЛОВА: психофизиология; дезадаптация; гингивит; пародонтит; молодой возраст; лечение.

\section{THE TACTICS SELECTION OF TREATMENT AND PREVENTIONAL MEASURES OF PERIODONTAL DISEASES OF PERSONS WITH DIFFERENT PSYCHOPHYSIOLOGICAL STATES}

M.A. Luchynskiy, L.V. Pyasetska

I. Horbachevsky Ternopil State Medical University, Ternopil, Ukraine

Purpose: to substantiate the choice of treatment and prophylactic schemes for the treatment of periodontal diseases in young age people depending on the psychophysiological state of the organism.

Materials and Methods. The study involved 48 people with inflammatory diseases of periodontal tissues and 52 persons with inflammatory-dystrophic periodontal tissue diseases with different psychophysiological state of the organism, which were divided into four treatment groups depending on the chosen treatment tactics.

Results and Discussion. The result of undertaken studies was that in the main therapeutic groups, therapeutic and prophylactic complexes included: hygiene education and upbringing; an individualized choice of oral care products based on the Green-Vermillion's index of hygiene, the intensity of lesions of periodontal tissues by the PMA index, and the implementation of professional oral hygiene. The treatment scheme for patients of control treatment groups was provided for by the effective standards for the treatment of periodontal tissue diseases.

Conclusions. In the treatment of periodontal diseases in this cohort, an important step is the individual and differentiated development and implementation of local and general therapeutic measures, taking into account the clinical and psychosomatic state of patients.

KEY WORDS: psychophysiology; disadaptation; gingivitis; periodontitis; young age; treatment.

Рукопис надійшов до редакції 22.06.2018 p.

\section{Відомості про авторів:}

Лучинський Михайло Антонович - доктор медичних наук, професор, завідувач кафедри терапевтичної стоматології ДВНЗ «Тернопільський державний медичний університет імені І. Я. Горбачевського МОЗ України»; тел.: +38(067) 415-60-87.

Пясецька Людмила Василівна - асистент кафедри ортопедичної стоматології дВН3 «Тернопільський державний медичний університет імені І. Я. Горбачевського МОЗ України»; тел.: +38(097) 662-59-62. 